\title{
Synthesis of New Mixed-Ligand Complexes of Molybdenum (IV) and Tungsten(IV): Characterization, Structure, Thermal and Anti-microbial Studies ${ }^{*}$
}

\author{
Festus Sunday Fabiyi ${ }^{1}$, Friday O. Nwosu ${ }^{2}$ \\ ${ }^{1}$ Department of Chemistry and Industrial Chemistry, Faculty of Science, Bowen University, Iwo, Nigeria \\ ${ }^{2}$ Department of Chemistry, Faculty of Science, University of Ilorin, Ilorin, Nigeria, E-mail: nwooyef@yahoo.com \\ Correspondence: Festus Sunday Fabiyi, Department of Chemistry and Industrial Chemistry, Faculty of Science, Bowen \\ University, Iwo, Nigeria. E-mail: sunfabiyi@yahoo.com or sunday.fabiyi@bowenuniversity.edu.ng
}

\author{
Received: January 3, 2019 Accepted: March 25, 2019 Online Published: March 27, 2019 \\ doi:10.5539/ijc.v11n1p43 \\ URL: https://doi.org/10.5539/ijc.v11n1p43
}

\begin{abstract}
Six new mixed-ligand complexes of $\mathrm{Mo}(\mathrm{IV})$ and $\mathrm{W}(\mathrm{IV})$ ions have been prepared and characterized. The three new complexes of $\mathrm{Mo}(\mathrm{IV})$ ions have the molecular formulae $\mathrm{MoC}_{12} \mathrm{~N}_{2} \mathrm{O}_{5} \mathrm{H}_{18}, \mathrm{MoC}_{15} \mathrm{~N}_{2} \mathrm{O}_{5} \mathrm{H}_{22}$ and $\mathrm{MoC}_{14} \mathrm{~N}_{2} \mathrm{O}_{6} \mathrm{H}_{19}$, while the $\mathrm{W}$ (II) ions are $\mathrm{WC}_{12} \mathrm{~N}_{2} \mathrm{O}_{5} \mathrm{H}_{18}, \mathrm{WC}_{15} \mathrm{~N}_{2} \mathrm{O}_{5} \mathrm{H}_{22}$ and $\mathrm{WC}_{14} \mathrm{~N}_{2} \mathrm{O}_{6} \mathrm{H}_{19}$. The structures of the complexes were deduced from their ir, ${ }^{1} \mathrm{H}$ nmr, and mass spectral studies. All the complexes were found to exhibit octahedral structures. Their antimicrobial activities against some bacteria and fungi species were found to be moderate.
\end{abstract}

Keywords: 8-Hydroquinoline, amino acids, mixed ligand, metal complexes

\section{Introduction}

Studies of metal-complexes have become very interesting because their syntheses and chemical studies have led to exploitation of both their striking physical and chemical properties for diverse applications (Perrin et al, Amit et al).

For this reason, researches in to syntheses and studies of metal complexes with diverse applications have been growing very fast (Perrin et al, Wangler et al). In fact, the number of metal complexes that can be synthesized seems limitless. This implies that the usefulness of these complexes can result to striking applications.

Novel metal complexes can be synthesized by changing the metal ions or the coordinating ligands which may, as well, involve structural modifications, such as, number of molecules (Fabiyi et al ), type of ligands, etc (Amit et al, Fabiyi et $a l$ and Mandegani et $a l)$.

Many first row transition metal ions complexes with 8-Hydroxyquinoline as the ligand, have been synthesized and reported to possess wide range of applications (Morgan et al, Nakamoto et al and Orjiekwe et al). A large number of metal complexes with mixed ligands have been synthesized and studied (Perrin et al). These group complexes have been found to have diverse usefulness, in biological processes such as enzymes activation, storage and movement of active materials. Some have been found to have anti-microbial and anti-tumor activities Mandegani et al, Orjiekwe et al and Sajadi et al).

Mixed ligand complexes of 8-Hydroxyquinoline and other ligands are among these reported complexes. Several first row transition metal ions mixed-ligand complexes of 8 -Hydroquinone and some amino-acids have been synthesized (Fabiyi et al, Nakamoto et al and Sajadi et al).

However, studies on their analogues of the second row transition metal ions with these ligands are still rare. Mixed ligand metal complexes chelates are very stable Sunil et al, Syamal et al and Wanger et al) and established to be biologically active against pathogenic micro-organisms (Sajdi et al, Syamal et al).

Their biological roles are known to be dependent on their stabilities. Previous researches have shown that the biological activities of some biologically active ligands are significantly increased when complexed with transition metal ions (Perrin et al, Sunil et al and Wanger et al). In this present study, we report the synthesis, structure and thermal behavior of six new mixed-ligand complexes of molybdenum and tungsten ions with 8-hydroxyquinoline as

\footnotetext{
${ }^{*}$ This research is partly sponsored by Bowen University, Iwo through granting travel leave to FSF.
} 
primary ligand, and alanine, leucine or glutamine as secondary ligands. Their antibacterial and fungal activities were also investigated.

\section{Experimental}

\subsection{Chemicals}

Reagents of Analar grade of the chloride salts of the metal from Sigma Aldrich chemicals were used as received, without further purification. All solvents were purified by distillation using conventional method before use (Syamal et al).

\subsection{Physicochemical Measurements}

The molar conductivities of $10^{-3} \mathrm{M}$ solution of the metal complexes in DMF were measured at $30^{\circ} \mathrm{C}$ using Equiptronics Digital Conductivity meter Model EQ-DCM-P. The melting points were determined using Gallenkamp AZ6512 melting point apparatus. Magnetic moments were measured at room temperature (Guoy's method) with Magnetic Susceptibility Balance, model Mk1, Sherwood Scientific, Cambridge.

Infrared spectra were recorded on FTIR Spectrophotometer (IR-Prestrige 21) in the region $4500-400 \mathrm{~cm}^{-1}$.

TGA/DTA studies were recorded on a Linesis STAPT-1000 (Pyris Diamond) thermal analyzer at a heating rate of $10{ }^{\circ} \mathrm{C}$ $/ \mathrm{min}$. in atmosphere of air and nitrogen at the flow rate of $50 \mathrm{~mL} \mathrm{~min}^{-1}$ in the temperature range of $50-1000{ }^{\circ} \mathrm{C}$.

${ }^{1} \mathrm{H}$ nmr sprectra were recorded on Bruker Avance 11400 NMR Spectrometer using DMSO d ${ }^{6}$ (spectroscopic grade) as solvent.

Electrochemical studies were carried out using EG \& G Priceton Galvanostat Model 273 A.

The elemental analyses were carried out using Thermo Finnigan Elemental Analyzer (model FLASH EA-1112).

Electronic spectra were recorded in DMSO on a Shimadzu UV-1600 Spectrophotometer.

\subsection{Antimicrobial Studies}

The qualitative antimicrobial susceptibility tests for the complexes were carried out using agar well diffusion technique (Sunil et al).

Each complex (20 mg) was dissolved in $50 \mathrm{~mL}$ of methanol, which was used as sample solution. Sample size for all the complexes was fixed at $0.1 \mathrm{~mL}$. The wells were made by scooping out agar medium with sterilized cork borer in a Petri dish which has been inoculated with the microorganisms. $0.1 \mathrm{~mL}$ solution of each complex was added in the wells and Petri dish was then incubated at $37{ }^{\circ} \mathrm{C}$ for $24 \mathrm{~h}$ in dark. Ampicillin was used as the standard antibacterial drug while the control solvent was dimethylformamide. Amphoterin B was used as the standard antifungal drug. Zone of inhibition (ZOI) produced by each complex was measured in $\mathrm{mm}$.

\subsection{Synthesis of the Complexes}

For the preparation of (1), $50 \mathrm{~mL}$ of freshly prepared solution of $\mathrm{MoCl}_{4}(0.236 \mathrm{~g}, 0.01 \mathrm{~mol})$ in absolute ethanol and 20 $\mathrm{mL}$ of 8 -hydroxyquinoline (HQ) ( $0.142 \mathrm{~g}, 1.00 \mathrm{~mol})$ in ethanol were mixed together and stirred vigorously. The reaction mixture was then placed immediately in a boiling water bath for 15 mins with constant stirring. Then $10 \mathrm{~mL}$ of aqueous solution of alanine $(0.005 \mathrm{~g}, 0.0125 \mathrm{~mol})$ was added.

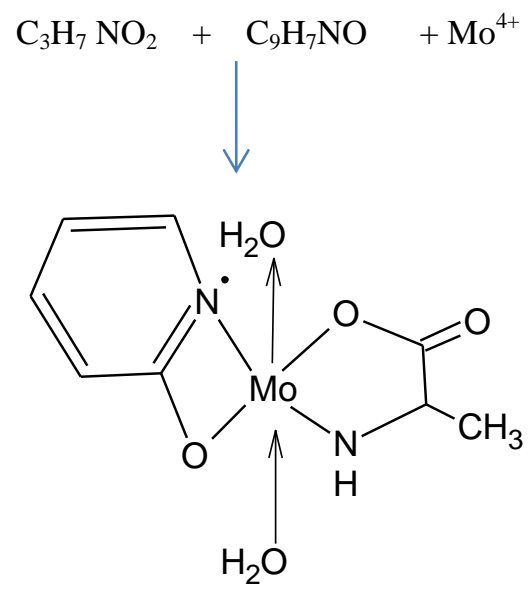

Fig.1. Proposed equation of reaction for the preparation of Mo complex with 8-hydroxyquoline and alanine

The $\mathrm{pH}$ of the reaction solution was then adjusted to about 8.5 using ammonium solution and, then, removed from the 
hot water bath. The reaction mixture was further refluxed for two hours and allowed to cool to room temperature. Crystals formed after $48 \mathrm{hrs}$ were removed, washed with water several times and then recrystallized twice using absolute ethanol and dried in a vacuum over phosphorous pentoxide $\left(\mathrm{P}_{2} \mathrm{O}_{5}\right)$.

The remaining five complexes were prepared by same procedure using the quantities of the reactants as follows:

For (2): $\mathrm{MoCl}_{4}$ (0.362 g, 0.24 mol.); 8-hydroxyquinoline (0.164 g, 0.24 mol.); Alanine (0.020 g, 0.026 mol.).

For (3): $\mathrm{MoCl}_{4}$ (0.362 g, $0.24 \mathrm{~mol}$.); 8-hydroxyquinoline (0.164 g, $0.24 \mathrm{~mol}$.); Glutamine (0.0380 g, $0.024 \mathrm{~mol}$.).

For (4): $\mathrm{WCl}_{4}(0.424 \mathrm{~g}, 0.22 \mathrm{~mol}$.); 8-hydroxyquinoline ( $0.20 \mathrm{~g}, 0.28 \mathrm{~mol}$.); Leucine ( $0.036 \mathrm{~g}, 0.031 \mathrm{~mol}$.).

For (5): $\mathrm{WCl}_{4}$ (0.424 g, $0.22 \mathrm{~mol}$ ); 8-hydroxyquinoline (0.20 g, $0.28 \mathrm{~mol}$.); Alanine ( $0.020 \mathrm{~g}, 0.026 \mathrm{~mol}$.).

For (6): $\mathrm{WCl}_{4}(0.424 \mathrm{~g}, 0.22 \mathrm{~mol}$ ); 8-hydroxyquinoline (0.20, $0.28 \mathrm{~mol}$.); Glutamine (0.040 g, $0.026 \mathrm{~mol}$.).

\section{Results and Discussion}

The physicochemical properties of the complexes are presented in Table 1. The percentage yields that obtained from the preparation of the six new complexes were appreciable as shown Table 1. Sharp melting points recorded for all the complexes indicate that the complexes were pure.

The chemical structures of all the complexes were deduced using information obtained from both their physical properties studies and spectroscopic analyses.

\subsection{Molar Conductance and Magnetic Moment Measurements}

The molar conductance measurements for the complexes are in the range $14.32-23.52 \mathrm{ohm}^{-1} \mathrm{~cm}^{2} \mathrm{~mol}^{-1}$. These indicate that the compounds are non-electrolytes. The magnetic moments showed that the complexes are all paramagnetic, hence, spin free $\mathrm{d}^{2}$ systems. These data are presented in Table 1.

$3.2{ }^{1} \mathrm{H} \mathrm{nmr}$

DL- alanine, L-glutamic acid were prepared in $\mathrm{D}_{2} \mathrm{O}$ while leucine in DMSO. Doublet signal of HCN-NH appear at 4.21 ppm (Table 2). The signals observed in the spectra were assigned after careful comparison with those found in the literature (Orjiekwe et al and Sunil et al). Ist was noted that the chemical shifts of the hydroxyl and amino groups were shifted to higher fields due to deprotonation and coordination, respectively. This confirms that the two groups are involved in the coordination.

Little differences were observed in the chemical shifts of the groups that are far from the metal ion the complexes. As expected in all the complexes, the chemical shift values of the hydroxyl and amino groups are shifted to the blue region due to deprotonation and coordination, respectively.

\subsection{Thermogravic Studies}

Thermogravic studies of the complexes was carried out at the rate of $10^{\circ} \mathrm{C} \min ^{-1}$ in inert atmosphere. The first weight loss by the complexes occurred in the range $95-182{ }^{\circ} \mathrm{C}$ which corresponds to the loss of two molecules of water. The endothermic peaks in the range $375-434^{\circ} \mathrm{C}$ and $590-635^{\circ} \mathrm{C}$ are indications of decompositions of the amino acid and 8 -hydroxyquinone moieties. This decomposition pattern was observed in the six complexes.

\subsection{I.R. Studies}

Important bands from the spectra (Table 3) of the free amino acids, 8-hydroxyl quinone and the metal complexes were selected and assigned after careful comparisons with literature(Wisniewska et al). The $3435 \mathrm{~cm}^{-1}$ stretching frequency which is rightly ascribed to $\mathrm{vO}-\mathrm{H}$ band observed in the free $\mathrm{HQ}$ did not appear at all in all the spectra of the complexes. This is an indication that the HQ is bonded to the metal ion through the $\mathrm{O}$ atom of the $-\mathrm{OH}$ group after deprrotonation. The bands around $468-462$ and $484-480 \mathrm{~cm}^{-1}$ are respectively, assigned to the stretching frequencies of $v M o-\mathrm{N}$ and $v \mathrm{~W}-\mathrm{N}$. This is a strong indication that the HQ is coordinated to the metal ion through $\mathrm{N}$ atom.

As expected, there is a hypochromic shift in the wave number observed for $v(\mathrm{C}=\mathrm{N})$ in the free HQ from $1585 \mathrm{~cm}^{-1}$ to $1472 \mathrm{~cm}^{-1}$. This suggested that the coordination is through the tertiary nitrogen donor of HQ. The strong bands at about $1120-1128 \mathrm{~cm}^{-1}$ observed in the spectra of the complexes are assigned to the $v(\mathrm{C}=\mathrm{O})$ bands which suggests the presence of HQ moiety in the complexes with coordination through its $\mathrm{N}$ and $\mathrm{O}$ atoms (Nogueira et al).

The bands observed at around 3035 and $\quad 2964 \mathrm{~cm}^{-1}$ are assigned as C-N asymmetrical and C-N symmetrical vibration wavelengths, respectively (Gharib et al). The bands shown in the regions of $610-602 \mathrm{~cm}^{-1}$ have been assigned to Mo-O and W-O vibration wavelengths. These did not appear in the spectra of the free amino acids.

The presence of coordinated water molecules in the complexes is indicated in the ir spectra of the complexes due to the presence of weak bands in the range $1580-1575 \mathrm{~cm}^{-1}$ which is assigned to H-O-H bending vibrations. 
The $v(\mathrm{COO})$ band of the free amino acids observed in the range $1605-1600 \mathrm{~cm}^{-1}$ is bathochromically shifted in the complexes to around $1380-1374 \mathrm{~cm}^{-1}$. This indicated that the coordination of the $\mathrm{COOH}$ group to the metal ion is via $\mathrm{O}$ (Feng et al).

In-plane and out of plane deformation modes were observed at about 525 and $578 \mathrm{~cm}^{-1}$, respectively in the HQ. These, however, occurred at higher wave numbers of $510 \mathrm{~cm}^{-1}$ and in the range of $788-782 \mathrm{~cm}^{-1}$. This indicates that the coordination through the $\mathrm{N}$ of $\mathrm{HQ}$ with the metal ions.

\subsection{Electronic Spectra Studies}

One intense peak in the region $382-425 \mathrm{~nm}$ was observed in the electronic spectrum of each of the six new complexes. Each of these is assigned as charge- transfer to metal (LMCT). All the complexes also each exhibited a weak band in the region $592-644 \mathrm{~nm}$ and these are attributed to $\mathrm{d}-\mathrm{d}$ transitions. The bands and their assignments are shown in Table 4. The spectra indicate that the geometry of the complexes is octahedral.

\subsection{Mass Spectra Studies}

In the mass spectra of complex (1) intense mass peaks at $\mathrm{m} / \mathrm{z} 366,328$ and 243 were shown.

The first mass peak corresponds to the $\left[\mathrm{MoC}_{12} \mathrm{~N}_{2} \mathrm{O}_{5} \mathrm{H}_{18}\right]^{+}$ion and the second one proceeds by elimination of two water molecules, while the third peak corresponds to elimination of two water molecules and alanine molecular ion. The mass spectra of complexes (2), (3), (4), (5), and (6) show peaks at 408, 421, 454, 494 and 509 which correspond to their [molecular $^{+}$ions peaks, respectively. These observations confirm the calculated molecular weights of the proposed structures for the compounds. The proposed typical structure of the complex is as shown in Fig. 2.

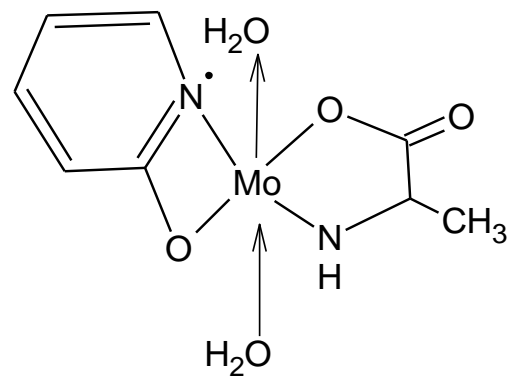

Fig.2. Proposed structure of one of the complexes

\subsection{Biological Studies}

All the complexes and ligands were screened for in vitro antibacterial activities against Escherichia coli, Staphylococcus aureus, Straphytomyces viginiae and Staphylococcus pneumonia and anti-fungal activities against Candida albicans, Agaricus bisporus, Actinocorallia herbida, Aspergillus flavus and Aspergillus niger.

The results of the antimicrobial activities of the six complexes are shown in Tables 5 and 6 . All of them possess moderate biocidal properties.

\section{Conclusion}

This study has revealed the structure and spectroscopic properties of six new mixed-ligand complexes of Mo(IV) and W(IV) ions. All the complexes have octahedral geometry. The antimicrobial studies revealed that the complexes have moderate antimicrobial activity against some bacteria and fungi. 
Table 1. Physical properties and elemental analysis of the complexes

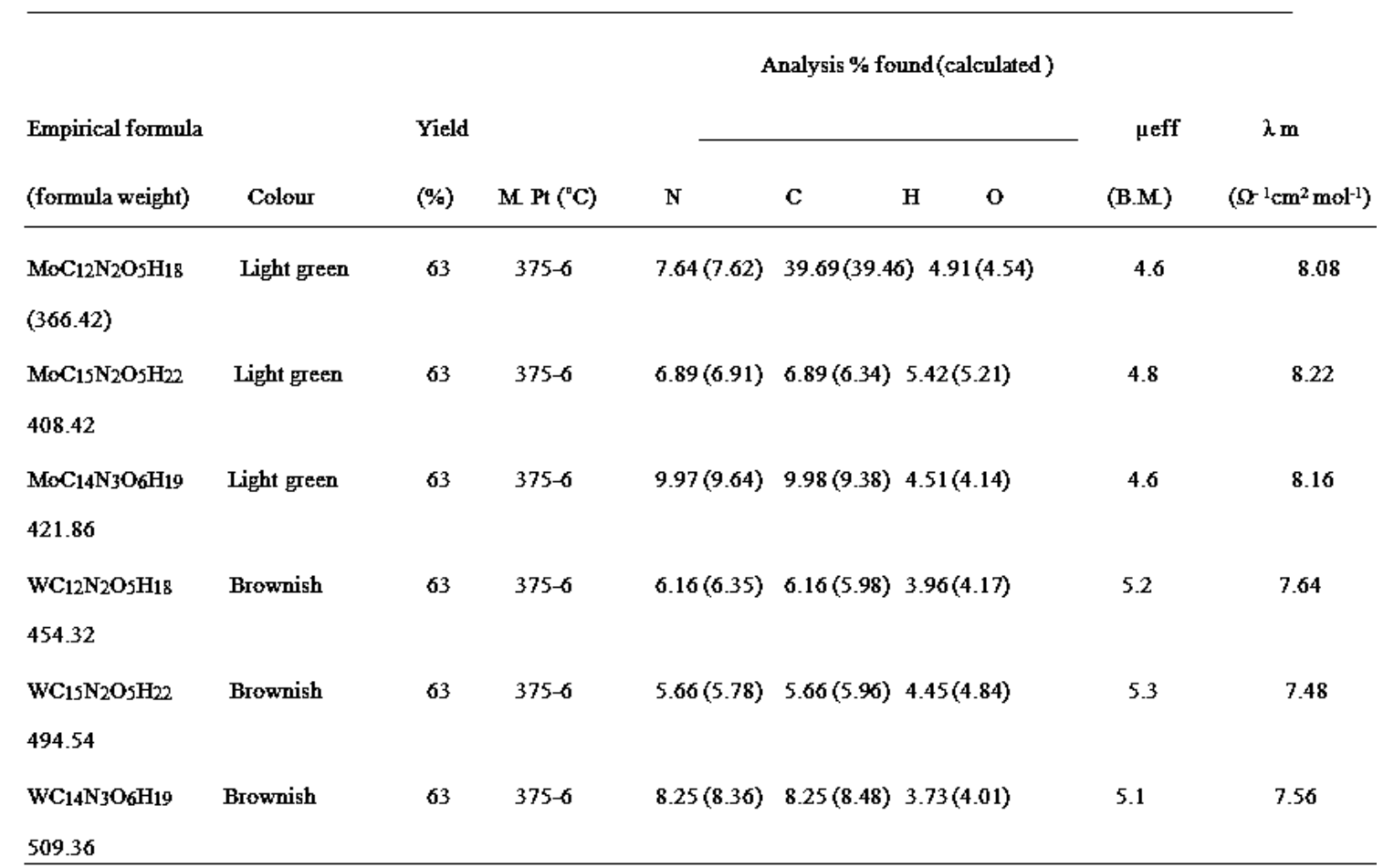

Table 2. ${ }^{1}$ HNMR spectra of the complexes

\begin{tabular}{|c|c|}
\hline Compound & ${ }^{1} \mathrm{HNMR}(\delta, \mathrm{ppm})$ \\
\hline Alanine & $1.69\left(\mathrm{~d}, 3 \mathrm{H}, \mathrm{CH}_{3}\right), 5.20(\mathrm{q}, 1 \mathrm{H}, \mathrm{CH}), 6.94(\mathrm{~s}, 1 \mathrm{H}, \mathrm{OH}), 6.09\left(\mathrm{~s}, 2 \mathrm{H}, \mathrm{NH}_{2}\right)$ \\
\hline Leucine & $\left.1.02\left(\mathrm{~d}, 6 \mathrm{H}, \mathrm{CH}_{3}\right), 1.52\left(\mathrm{~d}, 2 \mathrm{H}, \mathrm{CH}_{2}\right), 4.44(\mathrm{~s}, 1 \mathrm{H}, \mathrm{CH}), 2.19(\mathrm{q}, 1 \mathrm{H}, \mathrm{CH}), 8.30 \mathrm{~s}, 1 \mathrm{H}, \mathrm{OH}\right), 8.10\left(\mathrm{~s}, 2 \mathrm{H}, \mathrm{NH}_{2}\right)$ \\
\hline Glutamine & $4.20\left(\mathrm{t}, 2 \mathrm{H}, \mathrm{CH}_{2}\right), 5.10\left(\mathrm{q}, 2 \mathrm{H}, \mathrm{NH}_{2}\right), 5.64(\mathrm{~s}, 1 \mathrm{H}, \mathrm{OH}), 6.09\left(\mathrm{~s}, 2 \mathrm{H}, \mathrm{NH}_{2}\right)$ \\
\hline $\mathrm{MoC}_{12} \mathrm{~N}_{2} \mathrm{O}_{5} \mathrm{H}_{18}$ & $1.69\left(\mathrm{~d}, 3 \mathrm{H}, \mathrm{CH}_{3}\right), 5.20(\mathrm{q}, 1 \mathrm{H}, \mathrm{CH}), 6.94(\mathrm{~s}, 1 \mathrm{H}, \mathrm{OH}), 6.09\left(\mathrm{~s}, 2 \mathrm{H}, \mathrm{NH}_{2}\right)$ \\
\hline $\mathrm{MoC}_{15} \mathrm{~N}_{2} \mathrm{O}_{5} \mathrm{H}_{22}$ & $\left.1.02\left(\mathrm{~d}, 6 \mathrm{H}, \mathrm{CH}_{3}\right), 1.52\left(\mathrm{~d}, 2 \mathrm{H}, \mathrm{CH}_{2}\right), 4.44(\mathrm{~s}, 1 \mathrm{H}, \mathrm{CH}), 2.19(\mathrm{q}, 1 \mathrm{H}, \mathrm{CH}), 8.30 \mathrm{~s}, 1 \mathrm{H}, \mathrm{OH}\right), 8.10\left(\mathrm{~s}, 2 \mathrm{H}, \mathrm{NH}_{2}\right)$ \\
\hline $\mathrm{MoC}_{14} \mathrm{~N}_{2} \mathrm{O}_{6} \mathrm{H}_{18}$ & $4.20\left(\mathrm{t}, 2 \mathrm{H}, \mathrm{CH}_{2}\right), 5.10\left(\mathrm{q}, 2 \mathrm{H}, \mathrm{NH}_{2}\right), 5.64(\mathrm{~s}, 1 \mathrm{H}, \mathrm{OH}), 6.09\left(\mathrm{~s}, 2 \mathrm{H}, \mathrm{NH}_{2}\right)$ \\
\hline $\mathrm{wC}_{12} \mathrm{~N}_{2} \mathrm{O} 5 \mathrm{H}_{18}$ & $1.69\left(\mathrm{~d}, 3 \mathrm{H}, \mathrm{CH}_{3}\right), 5.20(\mathrm{q}, 1 \mathrm{H}, \mathrm{CH}), 6.94(\mathrm{~s}, 1 \mathrm{H}, \mathrm{OH}), 6.09\left(\mathrm{~s}, 2 \mathrm{H}, \mathrm{NH}_{2}\right)$ \\
\hline $\mathrm{wC}_{15} \mathrm{~N}_{2} \mathrm{O}_{5} \mathrm{H}_{22}$ & $1.69\left(\mathrm{~d}, 3 \mathrm{H}, \mathrm{CH}_{3}\right), 5.20(\mathrm{q}, 1 \mathrm{H}, \mathrm{CH}), 6.94(\mathrm{~s}, 1 \mathrm{H}, \mathrm{OH}), 6.09\left(\mathrm{~s}, 2 \mathrm{H}, \mathrm{NH}_{2}\right)$ \\
\hline $\mathrm{WC}_{14} \mathrm{~N}_{3} \mathrm{O}_{6} \mathrm{H}_{19}$ & $\left.1.02\left(\mathrm{~d}, 6 \mathrm{H}, \mathrm{CH}_{3}\right), 1.52\left(\mathrm{~d}, 2 \mathrm{H}, \mathrm{CH}_{2}\right), 4.44(\mathrm{~s}, 1 \mathrm{H}, \mathrm{CH}), 2.19(\mathrm{q}, 1 \mathrm{H}, \mathrm{CH}), 8.30 \mathrm{~s}, 1 \mathrm{H}, \mathrm{OH}\right)$, \\
\hline
\end{tabular}


Table 3. Physical properties and elemental analysis of the complexes

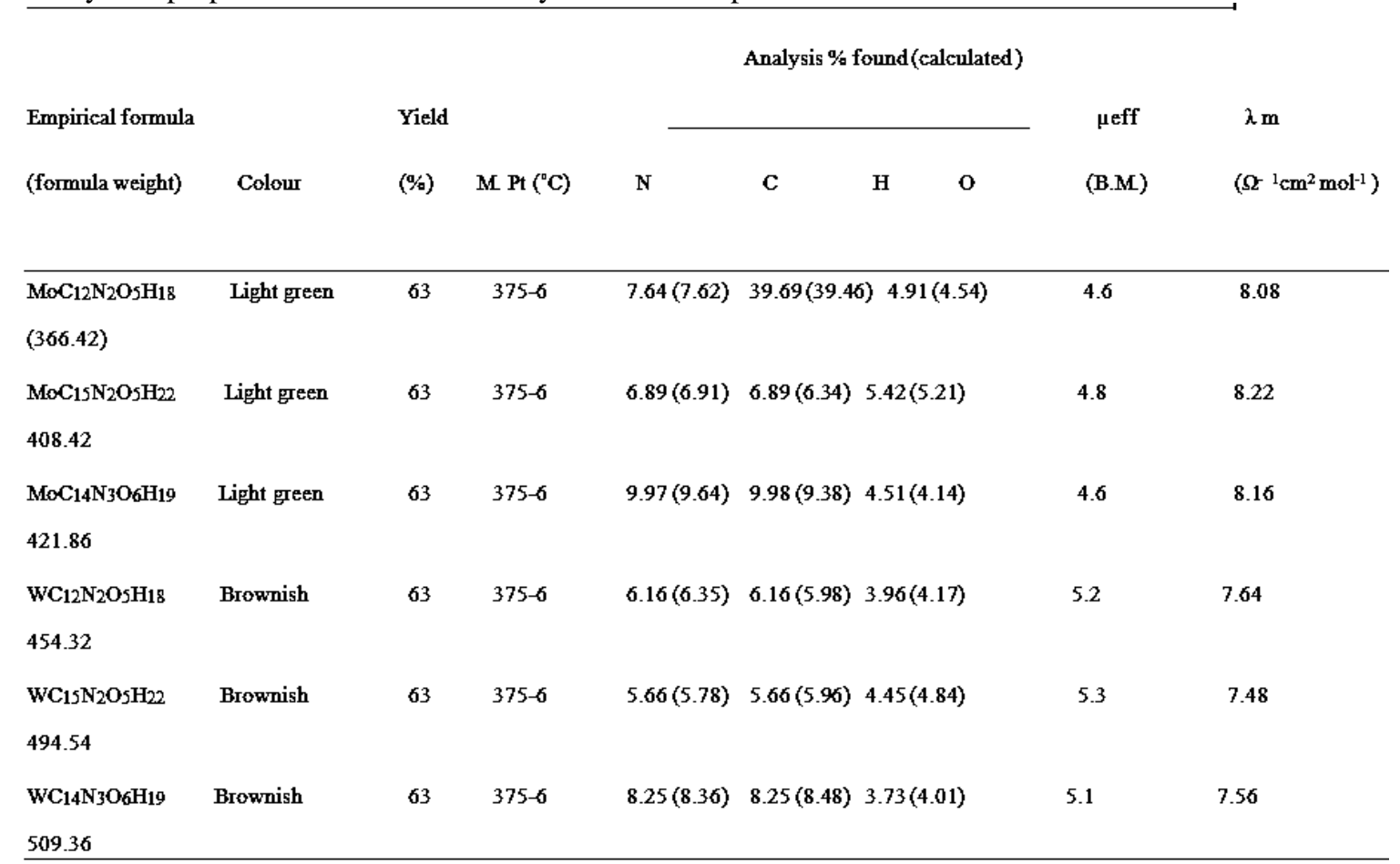

Table $4 .{ }^{1}$ HNMR spectra of the complexes

\begin{tabular}{ll}
\hline Compound & ${ }^{1} \mathrm{HNMR}(\delta, \mathrm{ppm})$ \\
\hline Alanine & $1.69\left(\mathrm{~d}, 3 \mathrm{H}, \mathrm{CH}_{3}\right), 5.20(\mathrm{q}, 1 \mathrm{H}, \mathrm{CH}), 6.94(\mathrm{~s}, 1 \mathrm{H}, \mathrm{OH}), 6.09\left(\mathrm{~s}, 2 \mathrm{H}, \mathrm{NH}_{2}\right)$ \\
Leucine & $\left.1.02\left(\mathrm{~d}, 6 \mathrm{H}, \mathrm{CH}_{3}\right), 1.52\left(\mathrm{~d}, 2 \mathrm{H}, \mathrm{CH}_{2}\right), 4.44(\mathrm{~s}, 1 \mathrm{H}, \mathrm{CH}), 2.19(\mathrm{q}, 1 \mathrm{H}, \mathrm{CH}), 8.30 \mathrm{~s}, 1 \mathrm{H}, \mathrm{OH}\right), 8.10(\mathrm{~s}, 2 \mathrm{H}, \mathrm{NH})$ \\
Glutamine & $4.20\left(\mathrm{t}, 2 \mathrm{H}, \mathrm{CH}_{2}\right), 5.10\left(\mathrm{q}, 2 \mathrm{H}, \mathrm{NH}_{2}\right), 5.64(\mathrm{~s}, 1 \mathrm{H}, \mathrm{OH}), 6.09\left(\mathrm{~s}, 2 \mathrm{H}, \mathrm{NH}_{2}\right)$ \\
$\mathrm{MoC}_{12} \mathrm{~N}_{2} \mathrm{O}_{\mathrm{H}} \mathrm{H}_{18}$ & $1.69\left(\mathrm{~d}, 3 \mathrm{H}, \mathrm{CH}_{3}\right), 5.20(\mathrm{q}, 1 \mathrm{H}, \mathrm{CH}), 6.94(\mathrm{~s}, 1 \mathrm{H}, \mathrm{OH}), 6.09\left(\mathrm{~s}, 2 \mathrm{H}, \mathrm{NH}_{2}\right)$ \\
$\mathrm{MoC}_{15 \mathrm{~N}_{2} \mathrm{O}_{5} \mathrm{H}_{22}}$ & $\left.1.02\left(\mathrm{~d}, 6 \mathrm{H}, \mathrm{CH}_{3}\right), 1.52\left(\mathrm{~d}, 2 \mathrm{H}, \mathrm{CH}_{2}\right), 4.44(\mathrm{~s}, 1 \mathrm{H}, \mathrm{CH}), 2.19(\mathrm{q}, 1 \mathrm{H}, \mathrm{CH}), 8.30 \mathrm{~s}, 1 \mathrm{H}, \mathrm{OH}\right), 8.10\left(\mathrm{~s}, 2 \mathrm{H}, \mathrm{NH} \mathrm{H}_{2}\right)$ \\
$\mathrm{MoC}_{14 \mathrm{~N}_{2} \mathrm{O}_{6} \mathrm{H}_{18}}$ & $4.20\left(\mathrm{t}, 2 \mathrm{H}, \mathrm{CH}_{2}\right), 5.10\left(\mathrm{q}, 2 \mathrm{H}, \mathrm{NH}_{2}\right), 5.64(\mathrm{~s}, 1 \mathrm{H}, \mathrm{OH}), 6.09\left(\mathrm{~s}, 2 \mathrm{H}, \mathrm{NH}_{2}\right)$ \\
$8.10\left(\mathrm{~s}, 2 \mathrm{H}, \mathrm{NH}_{2}\right)$ &
\end{tabular}

Table 5. IR spectra of the amino acids, 8-hydroxylquinoline and the new complexes

\begin{tabular}{|c|c|c|c|c|c|c|c|c|c|}
\hline Compound & $\mathrm{v}(\mathrm{OH})$ & $\mathrm{v}(\mathrm{C}=\mathrm{N})$ & $\mathrm{v}(\mathrm{N}-\mathrm{H})$ & $\mathrm{u}(\mathrm{C}-0)$ & $u(C=0)$ & $\mathrm{v}(\mathrm{MO}-0)$ & $v(W-0)$ & $v(M o-N)$ & $\mathrm{v}(\mathrm{W}-\mathrm{N})$ \\
\hline Hydroxylquinoline & $3445, \mathrm{~s}$ & 1585 & - & & $1585, \mathrm{~m}$ & - & - & - & - \\
\hline Alanine & $3476, \mathrm{~s}$ & & $3040, \mathrm{~m}$ & & $1590, \mathrm{~m}$ & - & - & - & -1 \\
\hline Leucine & $3466, \mathrm{~s}$ & & $3042, \mathrm{~s}$ & & $1588, \mathrm{~s}$ & - & - & - & - \\
\hline Glutamine & $3468, \mathrm{~s}$ & & $3042, \mathrm{~m}$ & & $1586, \mathrm{~m}$ & - & - & - & - \\
\hline $\mathrm{MoC}_{12} \mathrm{~N}_{2} \mathrm{O} 5 \mathrm{H}_{18}$ & $3306, \mathrm{~m}$ & $1470, \mathrm{~s}$ & $3188, \mathrm{~m}$ & $1105, \mathrm{~s}$ & $1610, \mathrm{~m}$ & $622, \mathrm{~s}$ & $638, \mathrm{~s}$ & $464, \mathrm{~s}$ & $482, m$ \\
\hline $\mathrm{MoC}_{15} \mathrm{~N}_{2} \mathrm{O} 5 \mathrm{H}_{22}$ & $3314, \mathrm{~s}$ & $1466, \mathrm{~s}$ & $3090, \mathrm{~s}$ & $1112, \mathrm{~m}$ & $1614, \mathrm{~s}$ & $624, m$ & $633, \mathrm{~m}$ & $468, m$ & $486, \mathrm{~s}$ \\
\hline 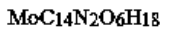 & $3304, \mathrm{~s}$ & $1468, \mathrm{~m}$ & $3086, \mathrm{~s}$ & $1118, \mathrm{~m}$ & $1616, \mathrm{~s}$ & $626, \mathrm{~m}$ & $640, \mathrm{~s}$ & $466, m$ & $488, \mathrm{~m}$ \\
\hline $\mathrm{wC}_{12} \mathrm{~N}_{2} \mathrm{O} 5 \mathrm{H}_{18}$ & $3306, \mathrm{~m}$ & $1467, \mathrm{~s}$ & $3082, \mathrm{~m}$ & $1116, \mathrm{~s}$ & $1612, \mathrm{~s}$ & $622, \mathrm{~m}$ & $642, \mathrm{~m}$ & $462, \mathrm{~s}$ & $484, \mathrm{~s}$ \\
\hline $\mathrm{wC}_{15} \mathrm{~N}_{2} \mathrm{O}_{5} \mathrm{H}_{22}$ & $3318, \mathrm{~s}$ & $1472, \mathrm{~s}$ & $3084, \mathrm{~s}$ & $1114, \mathrm{~s}$ & $1618, \mathrm{~s}$ & $620, \mathrm{~s}$ & $636, \mathrm{~m}$ & $464, \mathrm{~s}$ & $485, \mathrm{~s}$ \\
\hline 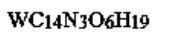 & $3304, \mathrm{~s}$ & $1470, \mathrm{~m}$ & $3088, \mathrm{~m}$ & $1114, \mathrm{~m}$ & $1615, \mathrm{~s}$ & $624, \mathrm{~s}$ & $638, \mathrm{~s}$ & $462, \mathrm{~s}$ & $490, m$ \\
\hline
\end{tabular}


Table 6. Electronic spectra studies data of the ligands and the complexes

\begin{tabular}{|c|c|c|}
\hline Complex & Electronic band $\left(\mathrm{cm}^{-1}\right)$ & Assignment \\
\hline \multirow[t]{2}{*}{ HQ } & 51,055 & $x \rightarrow x^{*}$ \\
\hline & 41,200 & $n \rightarrow n^{*}$ \\
\hline Alanine & - & - \\
\hline Leucine & - & - \\
\hline Glutamine & - & - \\
\hline \multirow[t]{3}{*}{1} & $87,650-86,500$ & ${ }^{4} \mathrm{~T}_{1 \mathrm{~g}} \mathrm{~g}(\mathrm{~F}) \longrightarrow{ }^{4} \mathrm{~T}_{1 \mathrm{~g}}(\mathrm{P})$ \\
\hline & $28,450-28,300$ & ${ }^{4} \mathrm{~T}_{1} \mathrm{~g}(\mathrm{~F}) \rightarrow{ }^{4} \mathrm{~A}_{2} \mathrm{~g}(\mathrm{~F})$ \\
\hline & $12,700-12,550$ & ${ }^{4} \mathrm{~T}_{1} \mathrm{~g} \rightarrow{ }^{4} \mathrm{~T}_{2} \mathrm{~g}(\mathrm{~F})$ \\
\hline \multirow[t]{3}{*}{2} & $87,350-87,000$ & ${ }^{4} T_{1} g(F) \longrightarrow{ }^{4} T_{1} g(P)$ \\
\hline & $28,250-27,000$ & ${ }^{4} \mathrm{~T}_{1} \mathrm{~g}(\mathrm{~F}) \longrightarrow{ }^{4} \mathrm{~A}_{2} \mathrm{~g}(\mathrm{~F})$ \\
\hline & $12,700-12,550$ & ${ }^{4} \mathrm{~T}_{1} \mathrm{~g} \rightarrow{ }^{4} \mathrm{~T}_{2} \mathrm{~g}(\mathrm{~F})$ \\
\hline \multirow[t]{3}{*}{4} & $87,350-86,500$ & ${ }^{4} T_{1} g(F) \longrightarrow{ }^{4} T_{1} g(P)$ \\
\hline & $22,350-22,000$ & ${ }^{4} \mathrm{~T}_{1} \mathrm{~g}(\mathrm{~F}) \longrightarrow{ }^{4} \mathrm{~A}_{2} \mathrm{~B}(\mathrm{~F})$ \\
\hline & $11,700-11,650$ & 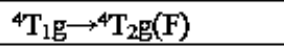 \\
\hline \multirow[t]{3}{*}{5} & $82,550-82,300$ & ${ }^{4} T_{1} g(F) \longrightarrow{ }^{4} T_{1} g(P)$ \\
\hline & $22,250-22,000$ & ${ }^{4} \mathrm{~T}_{1} \mathrm{~g}(\mathrm{~F}) \longrightarrow{ }^{4} \mathrm{~A}_{2} \mathrm{~g}(\mathrm{~F})$ \\
\hline & $11,700-11,550$ & ${ }^{4} \mathrm{~T}_{1} \mathrm{~g} \rightarrow{ }^{4} \mathrm{~T}_{2} \mathrm{~g}(\mathrm{~F})$ \\
\hline \multirow[t]{3}{*}{6} & $82,350-81,900$ & ${ }^{4} T_{1} g(F) \longrightarrow{ }^{4} T_{1} g(P)$ \\
\hline & $22,250-22,000$ & ${ }^{4} \mathrm{~T}_{1} \mathrm{~g}(\mathrm{~F}) \longrightarrow{ }^{4} \mathrm{~A}_{2} \mathrm{~g}(\mathrm{~F})$ \\
\hline & $11,500-11,350$ & 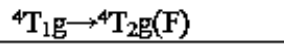 \\
\hline
\end{tabular}

Table 7. Antibacterial activity (ZOI in mm)

\begin{tabular}{lcccc}
\hline Compound & \multicolumn{5}{c}{ Bacteria } \\
\hline 1 & S. viginiae & S. pneumonia & S. aureus & E. coli \\
\hline 2 & 12 & 8.5 & 6.5 & 15.5 \\
\hline 3 & 13.2 & 9.2 & 6.5 & 16 \\
\hline 4 & 14.8 & 9.57 & 7.0 & 16.5 \\
\hline 5 & 13.5 & 8.8 & 6.5 & 16 \\
\hline 6 & 14.3 & 9.5 & 6.5 & 16.8 \\
\hline HQ & 14.8 & 10.2 & 7.0 & 17.5 \\
\hline Ala & 7.4 & 4.5 & 2.0 & 4.5 \\
\hline Leu & 3.5 & 2.5 & 0.5 & 1.5 \\
\hline Glu & 3.2 & 2.0 & 0.5 & 0.5 \\
\hline Ampicillin & 2.1 & 2.0 & 0.0 & 0.0 \\
\hline DMF & 48 & 34 & 27.5 & 32 \\
\hline
\end{tabular}


Table 8. Antifungal activity (ZOI in $\mathrm{mm})$

\begin{tabular}{lccccc}
\hline Compound & \multicolumn{5}{c}{ Fungus } \\
\hline 1 & C. albicans & A. bisporus & A. herbida & A. flavus \\
\hline 2 & 14.5 & 13 & & 7 & 10.5 \\
\hline 3 & 15 & 13 & 7.2 & 10.8 \\
\hline 4 & 16 & 13.4 & 7.5 & 10.5 \\
\hline 5 & 15.2 & 13 & 8 & 10.5 \\
\hline $\mathbf{6}$ & 15.5 & 13 & 8.5 & 11.5 \\
\hline HQ & 16.5 & 13.5 & 9 & 11.8 \\
\hline Ala & 4.2 & 3.5 & 2 & 3.5 \\
\hline Leu & 0.0 & 0.0 & 0.0 & 1.2 \\
\hline Glu & 0.0 & 0.0 & 0.0 & 0.0 \\
\hline Amphoterin B & 0.0 & 0.0 & 0.0 & 0.0 \\
\hline DMF & 28 & 32 & 26 & 28 \\
\hline
\end{tabular}

\section{References}

Abdel-Aziz, A. A. (2010). Synthesis, Spectroscopic Ccharacterization, Thermal Studies, Catalytic Epoxidation and Biological Activity of Chromium and Molybdenum hexacarbonyl Bound to Novel $\mathrm{N}_{2} \mathrm{O}_{2}$ Schiff Base. J. Mol. Struc., 979, 77-85. https://doi.org/10.1016/j.molstruc.2010.06.004

Amit, R. Y., Vijaya, V., \& Dhande-Anand, A. S. (2013). Synthesis and Characterization of Dioxotungsten(IV) Complexes of Chelating Hydrazone via Their Oxoperoxo Complexes. World J. of Chem., 8(2), 38-4.

Enemark, J. H., Cooney, J. J. A., \& Wang, J. J. (2004). Synthetic Analogues and Reaction Systems Relevant to The Molybdenum and Tungsten Oxotransferases. Chem. Rev., 104, 1175-1200. https://doi.org/10.1021/cr020609d

Fabiyi, F. A. S., Marcelo, N. R., \& Adewuyi, G. O. (2009). Thermal Stability of Mixed-valent Binuclear Osmium (II, III) carboxylates. Syn. React. Inorg. Metal-Org. Chem., 33, 64-72.

Feng, Z., Konstantin, V. B., Richard, R. S., Amir, H. H., \& Charlene, T. (2018). Syntheses of Molybdenum Oxobenzylidene Complexes. J. of Amer. Chem. Soc., 140(42), 13609-13613. https://doi.org/10.1021/jacs.8b09616

Gharib, F., \& Malekani, M. (2003). Ionic Strength Dependence of Formation Contants: Complexation of Histidine With Molybdenum(VI). Reviews in Inorg. Chem., 239(1), 97-109. https://doi.org/10.1515/REVIC.2003.23.1.97

Mandegani, Z., Asadi, Z., Asadi, M., Karbalaei-Heldari, H. R., \& Rastegari, B. (2016). Synthesis, Characterization, DNA Binding, Cleavage Activity, Cytotoxicity and Molecular Docking of New ater-soluble $\left[\mathrm{M}\left(5-\mathrm{CH}_{2}\right.\right.$ $\mathrm{PPh} 3,4$-salpyr $)]\left(\mathrm{ClO}_{4}\right)_{2} \quad(\mathrm{M}=\mathrm{Ni}, \mathrm{Zn})$ Complexes. Dalton Trans., 45, 6592-6611. https://doi.org/10.1039/C5DT04788A

Morgan, C. A., Greenhalgh, J. E. D., Sinclair, L. A., \& Wilkinson, R. G. (2002). Animal Nutrition, $7^{\text {th }}$ ed., Prentice Hall Pearson, 66-78.

Nakamoto, K. (1986). Infrared and Raman Spectra of Inorganic and Coordination Compounds. John Wiley and Sons, New York, $4^{\text {th }}$ ed., 233.

Nogueira L. S., Neves, P., Gomes, A. C., Lavrado, P., Cunha-Silva, L., Valente, A., .. Pillinger, M. (2018). Molybdenum(0) tricarbonyl and Tetracarbonyl Complexes With a Cationic Pyrazolylpyridine Ligands: Synthesis, Crystal Structures and Catalytic Performance in Olefin Epoxidation. Journal of RSC Advances, 29(2), 47-53. https://doi.org/10.1039/C8RA01687A

Orjiekwe, C. L., Fabiyi, F. A. S., \& Edward, D. A. O. (2005). Synthesis and Characterization of New Picolinate Metal Complexes. Syn. React. Inorg. Metal-Org. Chem., 28(2), 8-17. https://doi.org/10.1080/15533170500301895

Perrin, D. D., \& Agarwal, R. P. (1973). Metal ions in Biological Systems, Sigel H. C. Ed., 2, 167, Marcel Dekker, New York, 2, 167. 
Sajadi, S. A. A. (2010). Metal Ion-binding Properties of L-glutamic Acid and L-aspartic acid. A Comparative Investigation. Nat. Sci., 14, 85-90. https://doi.org/10.4236/ns.2010.22013

Sunil, S. P., Ganesh, A., \& Vishwanath, R. P. (2000). Synthesis, Spectral and Biological Studies on Some Mixed-ligand Ni(II) Complexes. Acta Pol. Pharm.-Drug Res., 66(3), 271-277.

Syamal, A., \& Maurya, M. R. (2012). Synthesis and Crystal Structures of Dioxomolybdenum (VI) Complexes With Catalytic Property. Syn. React. Inorg. Metal-Org. Chem., 42, 1167-1171. https://doi.org/10.1080/15533174.2012.684230

Wisniewska, A., Grubba, R., Ponikiewski, L., Zauliczny, M., \& Pikies, J. (2018). The New Diphosphanylphosphido Complexes of Tungsten (VI) and Molybdenum(VI). Their Synthesis, Structures and Properties. Dalton Transactions, 30(3), 2018.

\section{Copyrights}

Copyright for this article is retained by the author(s), with first publication rights granted to the journal.

This is an open-access article distributed under the terms and conditions of the Creative Commons Attribution license (http://creativecommons.org/licenses/by/4.0/). 